\title{
Sweet boys singing and rude boys rampaging: Revisiting Boys Keep Singing during an era of rising inequality and declining opportunity
}

\author{
Martin Ashley PhD \\ Editor-in-chief, ABCD Choral Directions Research
}

\begin{abstract}
Boys Keep Singing was an initiative released in 2008 to widen young male participation in the National Youth Choirs of Great Britain through improving choral and vocal education in schools and regional choirs. It received significant research council funding through demonstration of long-standing and persistent inequality. Significantly more girls than boys sang in choirs and those boys that did sing came disproportionately from independent, feecharging schools. The covid-19 pandemic of 2020 has seriously disrupted choral education, placing it on hold in many locations. However, it rings hollow to raise any alarm about a generation of boy singers "lost" to choirs since the majority did not participate in any case before the pandemic. Of greater concern are issues of rising social inequality and the emergence of a "digital divide" in access to remote learning. Boys' participation in choral singing is but one small indicator of this. Drawing upon what is known about adolescence and vocal identity, the paper considers possible consequences for choral singing. It concludes that if lost ground is to be regained, renewed efforts at remote knowledge transfer should be directed at rising generations of teachers. Boys' needs are for the direct support of those teachers.
\end{abstract}

\section{Key words}

Boys, singing, youth choirs, covid-19, adolescence, technology, judgement, equality, health, resilience.

\section{Introduction}

On the $23^{\text {rd }}$ March 2019, the government of the United Kingdom, in keeping with other governments across the world, announced a complete national lockdown in response to the exponential rise in hospitalisation and death from the novel SARS-CoV-2 virus. Little or no immunity in populations and no known cure were justifications for actions that were to have historic consequences. An immediate result was the cessation of all choral singing in the UK and most of the rest of the world. I wrote not long after that it was necessary to go back to the English civil war to find a comparable silencing of choirs. Choral singing, for example, continued throughout the First and Second World Wars. Only between the years 1652 and 
1660 were choirs silenced by political diktat (Ashley 2020a) when "rude boys"1 (former choristers) ran rampant, "breaking the Queen's chapel" and stealing lead from the roof of Canterbury Cathedral amongst other acts of delinquency (Price, 2016).

Eight years provided ample time for the annihilation of an entire generation of boy choristers. Those aged eight and above in 1652 would all have lost their unchanged voices by 1660 . Those aged below eight would have been infants or unborn at the onset of the civil war. Yet we read in the King's Cambridge records that in 1660, ten new choristers were immediately elected and by 1666, the full number of sixteen was attained. Mould (2007) records similar success at Lincoln and several other cathedrals. The repopulation of choirs with boy choristers at the Restoration was evidently accomplished with less difficulty than phrases such as "annihilation of an entire generation" might imply. Of those that were "lost" in the interim, we know little other than the scant records alluded to above. Any impulse to refer to a "lost generation" is understandable but given that this term originated with the millions of young lives lost in the First World War (Winter, 1977), temptation to hyperbole might better be resisted.

Nevertheless, initial concern with how choirs might stay together during lockdown and how quickly they might return to ways of life that existed before the pandemic has been relentlessly eroded by a growing realisation that the duration of the 2020/21 pandemic and its after-effects may be measured in years rather than months, and that the "normal" that existed before 2020 may never return in entirety. At the time of writing, it is too early to evaluate this possibility, but the prospect of at least one long winter with little or none of the activity promoted by the Boys Keep Singing Project (Ashley et al, 2009) provides the opportunity to re-evaluate that project and prepare for the situation that will be faced by the choral world when some form of post-pandemic equilibrium is achieved.

\section{Origins in inequality}

The Boys Keep Singing Project (ibid) received significant research council funding at a time when a UK government, more sympathetic than the present one, was receptive to advocacy for school singing. A persistent, apparently ineradicable gender imbalance in choral singing that crosses international boundaries had long been recognised (Koza, 1992; Harrison, 2007; Hall, 2015: Franklin, 2019) and the case for a project to involve more boys was easy to make. The National Youth Choirs of Great Britain (NYCGB) were keen to be involved and had alr eady begun to address the issue through courses specifically for boys aged between about ten and fourteen that recognised how voices began to change during early adolescence. Review of the then NYCGB demographic soon confirmed another fundamental inequality - that of income, social class and cultural capital. Boys from fee-charging independent schools (often supported by private singing coaching) were disproportionately represented in relation to boys from publicly funded maintained schools (Brewer, 2007).

\footnotetext{
1 "Rude" here is used as in the seventeenth century, being a synonym for uncouth, boorish, insolent. See Thurley, (2002)
} 
Accordingly, the title Widening Young Male Participation in Chorus was chosen specifically to reflect the intention to make NYCGB more accessible to children from diverse backgrounds. Funding was awarded at almost the same time (2008) as a $110 \mathrm{~m}$ investment by the then Department of Education and Skills (DES) in a National Singing Programme for Primary Schools, known as Sing-Up. An allocation was awarded from the Sing-Up programme to support the present author in working with the Chorister Outreach Programme (COP) established by the Choir Schools Association, an extension of work pioneered by Truro Cathedral. Evaluation of the Bristol Cathedral COP, known as Bristol Voices, confirmed and did much to explain the gender imbalance in favour of girls. It also revealed the extent to which a deeply ingrained inequality in opportunities for boys existed between maintained and independent schools across the region of Bristol and Avon (Ashley, 2007).

Later evaluation of the Boys Keep Singing Project (AHRC, 2014) revealed progress that was patchy and fragile. Success and good practice derived from Boys Keep Singing was cited and advocated in the National Music Plan (DCMS, 2011) but the evaluation for AHRC revealed important subtleties and nuances glossed over in the National Plan. A paper published in 2013 demonstrated the paradox that engagement with the underpinning seminal research of Irvine Cooper (originator of the cambiata concept of changing voices) was low in both independent and maintained schools, but for different reasons (Ashley, 2013). In the former, adherents of longstanding traditional approaches to male singing saw little reason to change practices. In the latter, it was more likely to be the case that there was no singing at all, with very little by boys even when there was (OFSTED, 2012).

It was as long ago as 1962 that Irvine Cooper toured the UK and found himself in disagreement with a then prevailing view amongst "public school masters" and cathedral organists who declared the voice to be 'useless' from the time it 'broke' to maturation in the early $20 \mathrm{~s}$. He was also distressed by what he found in the state-maintained schools - widespread ignorance of boys' voices, either no singing at all or a range of inappropriate vocal practices and a complete lack of any systematic training to address the problem. This situation has improved marginally during the last two decades. The widely recognised work of Cooper's student, the late John Cooksey (d2012) is better known in at least some of the independent schools and cathedrals. The work of knowledgeable vocal coaches has made some impact where previously a jealously guarded domain of organists with little knowledge of singing held sway (Chapman, 1995). Similarly, there is a small but not entirely uninfluential number of stateschool teachers knowledgeable in the management of young adolescent voices, some at least trained by the Boys Keep Singing project. Fundamentally, however, it rings hollow to raise a ny alarm about a generation of boy singers "lost" through the pandemic since the majority did not sing in any case before the pandemic. The situation in the decade leading up to the pandemic was well captured by OFSTED thus:

A secondary school head of music considered there was a strong culture of singing in the school, because the quality of singing in Year 7 lessons was good, there were some choirs and older students took part in an annual show. However, the repertoire of the Year 7 students was very limited. Singing 
was used for performance, but not to promote learning or explore musical ideas. The choirs were small and few boys attended. The productions involved a minority of students. Most students in the school did no singing at all. (OFSTED, 2013: 13)

\section{Old inequalities return}

The risks to life and health from choral singing, together with associated mitigations, have been well-researched and extensively documented since the outbreak of the pandemic (Mürbe et al, 2020; Gregson et al, 2020 and others). The risks of not singing have received less attention. The Data Evaluation and Learning for Viral Epidemics (DELVE) group convened by the Royal Society produced a report entitled Balancing the Risks of Children Returning to Schools (Royal Society, 2020). It concluded that the risks of opening schools were heavily outweighed by the risks of keeping them closed and devoted some 29, 300 words with 185 expert references to advocacy for the reopening of schools. Protracted closure of schools, it was argued, would result in three headline categories of risk:

- risks from loss of skills and increases in inequality

- risks to child and parent mental health

- risks from parents not being able to return to work.

After an initial summer-term lockdown culminating in a much-publicised government U-turn over public examinations, children have been back in school for almost a term at the time of writing. Whether the result of advocacy such as that of the DELVE group or a simple recognition that unschooled children and young people roaming the streets indefinitely was not a credible scenario, a way out of the "lives versus livelihoods" dilemma seems to have been found for the time being at least. That children are the lowest risk category for the SARSCoV2 virus has undoubtedly helped. Schools are far from back to normal, however, and an old problem has returned. Not once, in the 29,300 words of the DELVE report, do the words "music" or "singing" occur.

The choral singing and school music communities must thus advocate for themselves, much as they did in pre-covid times (Ashley 2014: 28-31). Interpretation of the DELVE report for music, and for boys' singing, might be part of that process. First on the list of DELVE's concerns is the risk of loss in skills and increase in inequality. It seems inevitable that skills will suffer some decline in most if not all subjects, but the loss may be recoverable. The data on rising inequality make the more alarming reading. Citing a meta-analysis by the Education Endowment Foundation the authors of DELVE argue that school closures could be expected to widen the attainment gap between poor and non-poor families with a median impact of $36 \%$ (the range of this estimate is between $11 \%$ and $75 \%$ ) by September 2020 . Such rises in inequality have indeed subsequently happened and are widely reported ( $\mathrm{Xu}$ and Blundell, 2020; Dorn, Hancock et al 2020, OFSTED, 2020 and many others). Although many of these rising inequalities are readily understood in terms of disadvantages to women and disadvantages to poorer children with limited access to on-line learning, it falls on studies 
such as the present one to investigate rising inequality in "peripheral" or "frill" areas such as music education and choral singing.

A report for the Incorporated Society of Musicians (Underhill, 2020), as might have been anticipated, provides evidence than the decline in music provision relative to other subjects has been rapid during the pandemic. The statistics cited in the report support the argument that inequality between subjects has increased. Music has fared particularly badly relative to most other subjects, but, as the report stresses, was in a poor place before the pandemic. The quantity and quality of music education, whilst never universally good in the maintained sector, has been in decline since the round of initiatives promoted by the New Labour government between 1997 and 2010 came to end. On inequality within the subject, the report has little to say. There is no analysis by criteria that might be indicative, and little acknowledgement that traditionally vulnerable areas of the subject, such as boys' singing, may have fared worse than others. Boys' singing is therefore in the unenviable position of having to advocate amongst the advocates.

Certainly, the situation in music and choral singing is not straightforward. Extensive evaluation of the Sing Up programme by Graham Welch and associates at the International Music Education Research Centre (iMerc) revealed that, though clear progress had been made by the Sing-Up programme, full equality between the genders was never achieved, with puzzling questions about developmental aspects of boys' and girls' musical learning being identified but not wholly answered. Significantly, the iMerc research also revealed important nuances relevant to poverty and social class. Identified as a "school factor" it was found that well-motivated and knowledgeable teachers working in poor neighbourhoods could achieve better results than teachers working in affluent areas that did not particularly value singing (Welch et al 2009). This mirrors the experience of both Boys Keep Singing and Bristol Voices. Skilled, committed teachers working in economically depressed areas were able to motivate young adolescent boys to sing where teachers in affluent schools either failed or were simply not interested (Ashley, 2007; 2013).

An abiding principle of BKS has been that teachers working in schools outside the cathedral system should be supported in their knowledge of how to provide for boys in singing during early adolescence (DCMS, 2011:44). However, inequality within the cathedral system itself has recently been noted by Leech (2020). Leech has been for some years associated with a highly regarded choral outreach programme in Leeds. He argues that equality of opportunity should be prioritised over artistic achievement on the grounds that the work of cathedrals should be directed at transforming lives. Crucially he backs his claim that this does not in the longer term come at the expense of artistic excellence, citing a lockdown performance of Taverner's great motet Quemadmodum ${ }^{2}$ by young singers - black, brown, white - from across Leeds, educated at state schools and one of six choirs running at the cathedral.

\footnotetext{
2 https://www.youtube.com/watch?v=GO5MFHGkM4s
} 


\section{Inequality and technology}

The Leeds performance of Quemadmodum shows what can be done when young people, already well-supported musically and committed to singing, have access at home to relatively simple technology. However, the DELVE report is replete with publications citing the consequences for rising inequality that arise from the lack of access to either the technology itself or the reliable broadband connections needed (Andrew et al, 2020 and 29 other studies cited by EEF). The term "digital poverty" has been coined by the media to draw attention to the scale of the problem, both in the UK and in the United States (Coughlan, 2020; Romm, 2020). New academic studies of the phenomenon are beginning to emerge, for example, Holmes and Burgess (2020).

There is emerging evidence of a new digital divide in youth singing. At one end of the scale are highly polished, professionally produced performances such as that of Leonard Cohen's Hallelujah by Roedean School, or the Bach motet Letze Studne, brich herein by the choristers of New College Oxford (see appendix). At the other end of the scale there appears, once again, to be no singing at all. Teachers' inability to meet pupils outside their covid-secure year "bubbles" appears to have dealt a fatal blow to initiatives to interest boys who might be described as more uncertain singers, a category that is considered shortly. An example of what young people maybe missing if their choirs do not embrace the new digital technologies is provided by the Ragazzi Boys Chorus of Northern California - situated in the heart of what has become known as "Silicon Valley". The Ragazzi have pioneered technology such as Google Classroom, Soundtap, Noteflight and a newly developed software solution to the problem of latency in applications such as Zoom.

\section{The Uncertain Boy Singer}

The origins of the "Zoom choir" might be traced to Eric Whitacre's celebrated "virtual choir". Konewko (2012) has analysed the nature of participation and social capital associated with this initiative. Whether in Leeds or Silicon Valley, digital or "Zoom" choir initiatives have now arisen out of necessity and appear to have been successful with boys already possessing social capital in choral singing and confident in their identity. These are young people who readily articulate their love for singing together in choirs. The majority do not fall into this category. Considerable effort was expended in trying to understand this majority in the years leading up to the launch of Boys Keep Singing. The term "uncertain singer" is justified by the finding that many boys like to sing - but privately, most commonly in the bathroom or perhaps in the bedroom where their "dad cannot hear them" (Ashley, 2014: 15). Boys are no different to other humans in experiencing the urge to sing, but fear of judgement, exacerbated by popular TV talent shows, ranked highly amongst the causes of boys' rejection of singing in public spaces. This raises important questions about the use of digital technology. Who will hear and judge what is committed to the mobile phone? What questions of trust arise? 
Young adolescent boys from any background can struggle to find an identity and if what they are asked to do with their voices goes contrary to what they perceive as necessary in their quest for identity, they will not sing (Ashley, 2009: 133-136). A mobile phone recording of the voice is a powerful mirror. The boy who has not had the benefit of informed teaching or the support of a good choir may struggle to reconcile his perception of such an image with his understanding of how singing is judged and by whom.

\section{"What works"}

Some fifteen years after its inception, it is possible to see where the Boys Keep Singing project got some things right and some things wrong. Significant sums were spent commissioning a professional media company to develop materials with the brief that boys who did sing should communicate with boys who did not. The producers were specifically asked to avoid anything like a traditional "talking heads" documentary or choir recruitment film. The result, though highly polished in terms of media sophistication, nevertheless failed to break free of traditional documentary film making. The problem faced by a project funded as knowledge transfer was that it is not knowledge that boys need but experience. Knowledge itself is relatively easy to transfer - to adults. In service training could be and was organised for music teachers and conductors. New choirs successfully started up largely where teachers already committed to the principle that boys should sing needed only additional knowledge of male puberty and the changing physiology of boys' voices during adolescence.

"What works" most of all for boys who may be sceptical or uncertain about singing is the legitimisation of the activity by other boys en masse. With the benefit of hindsight, thoug $h$ the project was right to recognise the importance of drawing boys into the company of other boys who sang together without apparent embarrassment or inhibition, it may be that the brief to the media company was an impossible one. It is tempting, now even more than in 2008 , to look to the way media such as Youtube are used by young "influencers" but the age group involved $(10-14)$ are probably too young to produce any such individual from their ranks, and were one to emerge he might be perceived as precocious or just "annoying".

For most boys, the uncertain singers, no substitute for a teacher (or conductor) who is a strong, confident, committed, and knowledgeable leader has yet been found. A boy might commit his voice to a mobile phone if he knows he is in the company of other boys doing the same thing without apparent embarrassment or inhibition, but "Zoom choirs" will make little sense to a new generation of boys who have little or no experience of singing together. Technology might sustain the confident singer but has little to offer as a means of advocacy or evangelism for the uncertain singer. The implications for increasing inequality when head teachers are unable or unwilling to allow boys to come together to experiment with voices are all too plain to see. 


\section{Inequality and Health}

Will this be a catastrophe? Those who believe that boys' participation in choral singing is important will derive little comfort from the failure of major initiatives such as the Sutton Trust $^{3}$ to act upon the assertion that music education has intrinsic value. The argument is admittedly a difficult one to make. Boys Keep Singing was conceived at a time when male violence, delinquency, mental health and under-achievement had been ongoing political concerns (Mills and Keddie 2007; Francis,2006; Ashley and Lee, 2003), leading the present author to argue the case in terms of music being an essential component of a well-rounded masculinity (Ashley, 2008a; 2010a; 2016). If "rude boys" of the seventeenth century broke the Queen's chapel and stole lead partly at least as the consequence of having no art through which to better themselves, then there is the thread of an argument that resonates with Mac an Ghaill's "3Fs" characterisation of artless boys (Fightin' Fuckin' n' Football", Mac an Ghaill, 2002). Art is at least shown to be a component of a better life, though a direct link in which choral singing of itself promotes health and wellbeing may be a step too far. Critical examination of the research literature reveals a less-certain picture.

Glew et al (2020) have recently undertaken a systematic integrative review of the literature addressing the effects of group singing on the wellbeing and psychosocial outcomes of children and young people. 634 records were retrieved by these authors' searches, but these were reduced to just thirteen eligible papers by their rigorous selection criteria. Overall, they were unable to conclude that the case for wellbeing through group singing by children and young people was substantially proven. Their analysis found many weaknesses in the studies reviewed, even the thirteen making the final selection. This they found surprising given stronger cases for adult singing that have been established by recognised authors in the field such as Clift, Hancox and associates of Sydney de Haan Research Centre for Arts and Health ${ }^{4}$.

This is less surprising, however, when it is considered that the wellbeing issues for adults may not be the same as for boys. For example, amongst the benefits demonstrated by the Sydney de Haan centre were respite for acute respiratory illness, Parkinson's disease, dementia, or most recently live music for care home residents (Skingley and Clerk, in press.) The prospects of demonstrating through methods such as randomised control trials that group singing improves the wellbeing of adolescent boys are very slender indeed. Effort might be better expended in understanding how the relationship between youth wellbeing and choral singing might withstand a setback such as the present pandemic. This requires consideration of a concept closely-linked to wellbeing, that of resilience.

\footnotetext{
${ }^{3}$ The Sutton Trust has funded one music project, First Thing Music in the Tees Valley. The justification is for improved outcomes in literacy. "While arts education is important for its own sake, the EEF's Arts Education literature review identified Kodály as an approach with some promise to also impact attainment outcomes, based on earlier studies."

${ }^{4}$ https://sidneydehaan.wordpress.com/
} 
Resilience has been defined as "the process of, or capacity for, or outcome of successful adaptation despite challenging or threatening circumstances (Masten et al, 1990). Alva (1991) described academically resilient students as those who 'sustain high levels of achievement motivation and performance despite the presence of stressful events and conditions that place them at risk of doing poorly in school and ultimately dropping out of school' (Alva, 1991:19). The covid children, almost by definition, are going to need resilience for they are living a childhood of challenging circumstances. Resilience research looks for explanations concerning why some individuals collapse when confronted with relatively minor setbacks, yet others press on cheerfully in the face of such extreme hardships as war, famine, fire, flood or bereavement. As resilience research has matured, medical deficit models have been increasingly discarded in favour of empirical life-history models (Doll \& Lyon, 1998; Howard \& Johnson, 1999; Rhee et al, 2001; Ungar, 2008; Martin and Marsh, 2009).

Liebenberg (2020) has recently examined this strain of literature and concluded that the lifehistory approach is valid but that the interaction between personal assets and relational resources in challenging situations is still not adequately understood. The current situation confronting boys and choral singing perhaps affords another context in which to progress understanding. Influential in the formulation of Boys Keep Singing were papers published by the present author between 2002 and 2006 detailing in-depth ethnographic work with the eighteen boys of a major city centre church choir. One of these papers, published in 2002, was unable to demonstrate a direct link between singing and health but raised important questions about both resilience and equality of opportunity that need to be revisited at the present time (Ashley, 2002). Rhee et al (2001), synthesised three core principles common to resilient individuals from what they described as three decades of longitudinal life history research:

- Caring, supportive adult in the life of the child or adolescent

- Opportunities for initiative or involvement in meaningful activities

- High expectations for behaviour

Through their membership of the choir, the boys had good access to these. Clearly, there are many circumstances that would afford access to such a supportive socio-ecological context, said to be at least as an important-if not more important- determinant of resilience as individual variables (Tol et al, 2013: 456). It would be a council of despair to base singing advocacy on this alone. However, under present circumstances it is justifiable to ask what the effect might be of withdrawing the influence of a caring, supportive adult who held high expectations for behaviour in a meaningful activity. The relevance of the question lies in the fact that the boys had chosen the choir as their meaningful activity and devoted a significant portion of their lives to it. Moreover, those of them that attended state-maintained schools referred constantly to what they regarded as poor quality music provision and abysmal choral programmes in their schools, gaining a strong sense of identity through membership of a choir that made high demands of them that they were able to meet. 
Perhaps of even greater significance was their recognition that there was a gender issue in choral music that their schools were failing to deal with. Accounts were given of how they negotiated a culture of singing being only for girls that led the author to investigate further the relationship between boys' singing and resilience. Why were some boys able to resist peer pressure against singing when a majority could not? A seminar paper presented at the University of Queensland during a visiting professorial scholarship in 2012 summarised several publications (Ashley, 2008b; 2010a; 2010b; 2011) and asked the question "are girls more resilient than boys?" (Ashley, 2012). The question was justified by work undertaken after 2008 with a much larger sample of boys in schools across the UK, many of whom who were, as described above, "uncertain singers". These data consistently showed boys dropping out of singing when confronted by setbacks in front of girls, or critical comments made by girls. The difference between these boys and the boys who remained in choirs where schools had stronger choral programmes could be summarised as:

- The support and encouragement of a gifted and committed teacher

- The company and solidarity of a significant number of other boys engaging in the same activity without embarrassment

It is not hard to see the threat to such conditions imposed by restrictions such as limits on numbers and confinement to "year bubbles" (assuming singing is allowed at all), or just the sheer scale of the task faced by school managements in maintaining "covid-secure" conditions. Lest they be forgotten, it is worth restating the five key factors common to the schools where gifted and committed teachers were found to be successful in engaging significant numbers of boys in singing. The references in parenthesis refer to the corroborating sources presented in the AHRC Impact Report where these five conditions are found:

1. A real commitment to boys' participation in the arts, supported by the senior leadership team of a school or setting. (Refs $a, f$ )

2. A willingness to organise school timetables to avoid, wherever possible, a clash between singing and sport. (Ref b)

3. A willingness to experiment with opportunities for boys to explore voices without the presence of girls, such as setting music classes by gender or the provision of parallel, single sex extra-curricular activities (Ref c).

4. Music teachers' and choir conductors' knowledge of and the ability to apply key research findings on the changes that happen to boys' voices between the ages of 10 and 15. (Ref e) 5. A willingness to celebrate the achievements of boys who sing, for example through performing to primary school children as ambassadors for the school. (Ref b)

(AHRC Impact Case Study, 2014)

\section{Where do we go from here?}

The very nature of the pandemic has made the task for researchers very much harder. Quality access to schools, teachers and, most importantly, individual pupils has become for 
understandable reasons all but impossible. Patience and a view that stretches beyond the immediate are going to be necessary. We must work from what we already know and plan for research that might be undertaken after the pandemic. It is unlikely that quality knowledge will result from hastily constructed or implemented surveys.

Whilst it is possible to see a threat to boys' participation in choral singing, history also shows us a source of resilience. Choirs were re-established quickly at the 1660 Restoration because the knowledge and skills of musicians and clerks survived the eight years of the Commonwealth. The hope is that existing bases of knowledge and skill in teachers and conductors will have fewer than eight years to survive the present pandemic. It would be foolish, though, to neglect the welfare of these individuals in the interim. Their needs for recognition and support are pressing and they are clearly the most fundamental and indispensable of the resources needed to sustain any culture of boys' singing. Neither should the process of knowledge transfer to a new generation of younger teachers be halted. Indeed, any issues of potential rising inequality need to be identified and incorporated in any recovery training plans. Are (less resilient) boys abandoning singing more rapidly than girls? There has been some anecdotal evidence to suggest that this might be so, in which case there is a need for investigation and supportable evidence. Will the fact that boys attending independent schools have been allowed to sing in cathedrals whilst boys attending state schools have been largely silenced have any lasting effect on already known inequality?

Questions such as these, however, appear trivial in relation to the issues raised by DELVE, or some of the studies that are now examining digital poverty and the widening gulf between the north and south of England ("levelling down"). Large scale studies such as the ESRC funded Co-SPACE (Cresswell, Waite et al, 2020) which aims to "support children, parents and adolescents during epidemics" are gathering important information. Data are now coming in from the schools inspectorate that confirm many of the fears of rising inequality and falling mental health (OFSTED, 2020). It is salutary that the NHS report Mental Health of Children and Young People in England, 2020 (Vizard, Sadler et al, 2020) employs the term "probable mental disorders" (my emphasis). Much of the information in that report is indirect and inferential, perhaps inevitably so given the timescales. Nevertheless, the need to investigate just how probable and what the true outcomes of the pandemic will be is obvious.

It falls to researchers such as the present author to ensure that the true outcomes of the pandemic for a small niche such as boys' singing are not neglected. It has not passed unnoticed by a researcher who has built his career principally on ethnography and patient, meaningful conversations with boys that the voice of the child appears relegated to an afterthought for Co-SPACE. Tellingly, that project informs parents that

We also interested in adolescents' views. If the child who you answer the surveyabout is aged between 11-17 years, when you get to the end of the survey there is an option for them to also take part. 
An "option at the end of the survey" is unlikely to obtain information of the quality that informed Boys Keep Singing.

\section{Conclusions}

Three principal conclusions might be drawn from the foregoing discussion. First, there is a need for patience. Everybody, from the conductor who "has not stood in front a choir for six month" to the researcher who is denied access to schools and children is going to have to be patient and rebuild their lives after the pandemic. Second, those teachers who possess the knowledge, skill and commitment needed to organise singing for boys and motivate boys to participate are a rare and precious resource. Their work must not go unrecognised and their needs for support and sustenance must not go unmet.

Finally, the boys themselves. Perhaps those that were singing before the pandemic, even from outside the independent sector, were a relatively privileged or well-provided for minority. Nevertheless, the point has been raised that to thrive as resilient individuals, young people need discipline and the support of caring adults who provide meaningful activities. If a boy has chosen a choir as his principal or only means of access to meaningful activity, the loss of the discipline and care associated with it could hit hard. We owe it to the boys who sing to provide care, meaning and discipline in their lives for as long as a pandemic might silence their collective voices. Ways may need to be found of sustaining the care and meaning even during the darkest times when there is no singing. The year is not 1652.

\section{References}

AHRC (2014) Impact case study on widening young male participation in chorus, Research Excellence Framework, 2014, Unit of Assessment 25, Education. Ormskirk, Edge Hill University.

Alva, S. (1991) Academic invulnerability among Mexican-American students: the importance of protective resources and appraisals. Hispanic Journal of Behavioural Sciences, 13: 18-34.

Andrew, A., Cattan, S., Costa-Dias, M., Farquharson, C., Kraftman, L., Krutikova, S., Phimister, A. and Sevilla, A. (2020). Learning During the Lockdown: Real-Time Data on Children's Experiences During Home Learning. IFS Briefing Note BN288. Available at: https://www.ifs.org.uk/uploads/BN288-Learning-during-the-lockdown-1.pdf

Ashley, M. (2020a) Where have all the singers gone, and when will they return? Prospects for Choral Singing after the SARS-CoV-2 Pandemic, ABCD Choral Directions Research, supplementary edition, https://www.abcd.org.uk/storage/Choral_Directions_Research/Where_have_all_the_singers gone_ publication_version.pdf

Ashley, M. (2008a) Teaching Singing to Boys and Teenagers: the young male voice and the problem of masculinity, Lampeter: Mellen. 
Ashley, M. (2008b) 'Boyhood Melancholia and the Vocal projection of Masculinity', Thymos: journal of boyhood studies 2 (1): 26-39.

Ashley, M. (2014) Singing in the Lower Secondary School. Oxford: OUP.

Ashley, M. (2013) 'Broken voices or a broken curriculum? the impact of research on UK school choral practice with boys', British Journal of Music Education, 30 (3): 311-327.

Ashley, M. (2012) Are girls more resilient than boys? Lessons in gender justice from the Boys Keep Singing project. Visiting professorial seminar paper presented at University of Queensland, Brisbane, Australia, February.

Ashley, M. (2011) The angel enigma: experienced boy singers' perceptual judgements of changing voices, Music Education Research, (13)3: 343-354

Ashley, M. (2010a) '"Real boys" don't sing, but real boys do: the challenge of constructing and communicating acceptable boyhood', THYMOS: Journal of Boyhood Studies 4 (1): 54-69.

Ashley, M. (2010b) '"Slappers Who Gouge Your Eyes": vocal performance as exemplification of disturbing inertia in gender equality', Gender and Education 22 (1): 47-62.

Ashley, M. (2009) How High Should Boys Sing? gender, authenticity and credibility in the young male voice. Aldershot: Ashgate.

Ashley, M. (2007) Singing High, Aiming High: an evaluation of the Bristol Voices singing challenge. Bristol: UWE.

Ashley, M. (2006) The Creative Education Project: arts enrichment in the Opportunity Network, Bristol: Bristol City Council Arts Service.

Ashley, M. (2002) 'Singing, Gender and Health: Perspectives from Boys Singing in a Church Choir'. Health Education 102 (4): 180-187.

Ashley, M., Howard, D. And Williams, J. (2009) Boys Keep Singing. Filmed material, directed by Tom Blackham, Liverpool: River Media.

Ashley, M. and Lee, J. (2003) Women Teaching Boys. Stoke-on-Trent: Trentham.

Brewer, M. (2007) Personal communication

Chapman, J. (1995) An English Case Study: The journey of a boy treble to Oxbridge choral scholar to adult professional soloist. Munich: Proceedings of the Pan European Voice Conference and German Singing Teachers Conference.

Cresswell, Waite, et al (2020) Covid 19: Supporting Parents, Children and Adolescents during Pandemics. University of Oxford Co-SPACE study. Co-Space Study: Supporting Parents, Adolescents and Children during Epidemics - Department of Experimental Psychology (ox.ac.uk)

Civinini, C. (2020) Teacher workload 'unsustainable' during lockdown, Times Educational Supplement, $21^{\text {st }}$ July. https://www.tes.com/news/teacher-workload-unsustainable-duringlockdown 
Coughlan, S. (2020) 'Digital poverty' in schools where few have laptops. BBC News on-line, $23^{\text {rd }}$ April, accessed 25 $5^{\text {th }}$ November. https://www.bbc.co.uk/news/education-52399589

Covington, M. (1992). Making the grade: A self-worth perspective on motivation and school reform. New York: Cambridge University Press.

DCMS (2011) The Importance of Music: a national plan for music education. London:

Department for Education and Department for Culture Media and Sport. DFE-00086-2011

Doll, B. and Lyon, M. (1998) Risk and Resilience: Implications for the Delivery of Educational and Mental Health Services in Schools, School Psychology Review, 27(3): 348-63.

Dorne, E. Hancock, B and Viruleg, E. (2020) Student learning and Covid-19 in the United States: the hurt could last a lifetime. Washington DC: McKinsey and Company. COVID-19 and student learning in the United States: The hurt could last a lifetime (mckinsey.com)

Glew, S., Simonds, L. and Williams, E. (2020) The effects of group singing on the wellbeing and psychosocial outcomes of children and 7 young people: a systematic integrative review. Guildford, University of Surry preprint.

Gregson; Watson; Orton; Haddrell; McCarthy; Finnie; et al. (2020): Comparing the Respirable Aerosol Concentrations and Particle Size Distributions Generated by Singing, Speaking and Breathing. ChemRxiv. Preprint. https://doi.org/10.26434/chemrxiv.12789221.v1

Francis, B. (2006) Heroes or Zeroes? The discursive positioning of 'underachieving boys' in English neo-liberal educational policy. Journal of Educational Policy, 21(2): 187-200.

Franklin, A. (2019) Gender and Singing in the American Classroom. Honors Program Theses. 86. https://scholarship.rollins.edu/honors/86

Hall, C. (2015) Singing, gender and class: understanding choirboys' musical habitus, in P. Buranard, Y. Trulsson and J. Soderman (eds) Bourdieu and the Sociology of Music Education. Abingdon: Routledge. 43-62.

Holmes, H. and Burgess, G. (2020) Pay the wi-fi or feed the children: coronavirus has intensified the UK's digital divide https://www.cam.ac.uk/stories/digitaldivide

Howard, S. D., J. and Johnson, B. (1999) Childhood resilience: Review and critique of the literature. Oxford Review of Education, 25(3): 307-323.

Konewko, M. (2012) "Actual Connections in a Virtual World: Social Capital of Eric Whitacre's Virtual Choir" Athens: ATINER'S Conference Paper Series, No: ART2012-0205.

Koza, J. (1992) 'The Missing Males and other gender related issues in music education, 19141924', Journal of Research in Music Education 41 (3): 212-232. 
Leech, T. (2020) Inspiring elite performance without the elitism, Arts Professional, $23^{\text {rd }}$ September. Inspiring elite performance without the elitism | ArtsProfessional

Liebenberg, L (2020) Reconsidering interactive resilience processes in mental health: Implications for child and youth services, Journal of Community Psychology, 48 (5): 1365 1380. https://doi.org/10.1002/icop.22331

Mac an Ghaill, M. (2002). Boyhood Melancholia. Key note address: Expert symposium: Society Modelling and Inclusion, Centre for Research in Education and Democracy, University of the West of England, Bristol.

Martin, A. and Marsh, H. (2009) Academic resilience and academic buoyancy: multidimensional and hierarchical conceptual framing of causes, correlates and cognate costructs. Oxford Review of Education, 35(3): 353-370.

Masten, A., Hubbard, J., Gest, S., Tellegen, A., Garmezy, N. and Ramirez, N. (1999) Competece in the context of adversity: Pathways to resilience and maladaption from childhood to late adolescence. Development and Psychopathology, 11 143-169.

Mills, M. and Keddie, A. (2007) Teaching boys and gender justice. International Journal of Inclusive Education, 11 (3) 335-354.

Mürbe, D., Kriegel, M. Lange, J., Rotheudt, H. and Fleischer, M. (2020) Aerosol emission is increased in professional singing, DOI: 10.31219/osf.io/znjeh

Aerosolemission is increased in professional singing (tu-berlin.de)

OFSTED (2020) Children hardest hit by COVID-19 pandemic are regressing in basic skills and learning. Press briefing, $10^{\text {th }}$ November. https://www.gov.uk/government/news/ofsted-children-hardest-hit-by-covid19-pandemic-are-regressing-in-basic-skills-and-learning?utm source=d3685 ef3-5064-4986-84e6-

6a19a55f797e\&utm medium=email\&utm campaign=govuk-notifications\&utm content=daily

OFSTED (2013) Music in Schools: what hubs must do. Office for Standards in Education report 130231. Manchester: DfE.

OFSTED (2013) Music in Schools: promoting good practice. Manchester: Office for Standards in Education.

OFSTED (2012) Music in Schools, wider still and wider: quality and inequality in music education 2008 - 2011. Office for Standards in Education report 110158. Manchester: DfE.

Mould, A. (2007) The English Chorister: a history. London: Hambledon/Continuum.

Price, C. (2016) "Useless in the choir": the music and musicians of Canterbury Cathedral 17001760. Paper presented at 17th Biennial International Conference on Baroque Music, Canterbury Christ Church University, $13^{\text {th }}-17^{\text {th }}$ July. 
Rhee, S., Furlong, M. and Turner, J. H., I. (2001) Integrating strength-based perspectives in psychoeducational evaluations. The California School Psychologist, 6: 5-17.

Romm (2020) Lost it...fucking idiot. But try this instead: Schooling During the COVID-19 Pandemic (census.gov)

Royal Society [DELVE] (2020) Balancing the risks of pupils returning to school. Data Evaluation and Learning for Viral Epidemics multi-disciplinary group report, July $24^{\text {th }}$. https://rs-delve.github.io/reports/2020/07/24/balancing-the-risk-of-pupils-returning-to-schools.html

Skingley, A. and Clark, N. (in press) The Musical Walkabout: providing access to individualised, live music for care home residents. Nursing and Residential Care.

Thurley, S. (2002) The Stuart Kings, Oliver Cromwell and the Chapel Royal 16181685', Architectural History, 45: 238-274.

Tol, W., Song, S., and Jordans, M.(2013). Annual research review: Resilience and mental health in children and adolescents living in areas of armed conflict-A systematic review of findings in low- and middle-income countries. Journal of Child Psychology and Psychiatry and Allied Disciplines, 54(4): 445-460. https://doi.org/10.1111/jcpp.12053

Underhill, J. (2020) The Heart of the School is Missing: music education in the covid-19 crisis. Report for the Incorporated Society of Musicians (ISM), $5^{\text {th }}$. December. ISM UK-Music-Teachers-survey-report Dec-2020 A4 ONLINE-2.pdf

Ungar, M. (2008) Resilience across cultures. British Journal of Social Work, 38 218-235.

Vizard, T. Sadler, K. (2020) Mental Health of Children and Young People in England, 2020: Wave 1 follow up to the 2017 survey. NHS Digital: Mental health of young people surveys. Mental Health of Children and Young People in England, 2020: Wave 1 follow up to the 2017 survey - NHS Digital

Welch, G., Himonides, E., Saunders, J., Papageorgi, I., Vraka, M., Preti, C. and Stephens, C. (2009) Researching the second year of the National Singing Programme in England: An ongoing impact evaluation of children's singing behaviours and singer identity. London: Institute of Education, Department of Arts and Humanities.

Winter, J. (1977) Britain's 'lost generation' of the first world war, Population Studies, 31(3): 449-466. https://doi.org/10.2307/2173368

$\mathrm{Xu}, \mathrm{X}$. and Blundell, R. (2020) Covid-19: the impacts of the pandemic on inequality, Presentation for Institute of Fiscal Studies, Deaton Review. Inequality: the IFS Deaton Review 


\section{Appendix}

Corroborating sources for AHRC Impact report

a) Authored Book: Ashley, M. (2009) How High Should Boys Sing? Gender, authenticity and credibility in the young male voice. Aldershot: Ashgate

b) Journal Article: Ashley, M. (2010) "Real boys" don't sing but real boys do: the challenge of constructing and communicating acceptable boyhood. THYMOS Journal of Boyhood Studies, 4 (1) $54-69$.

c) Journal Article: Ashley, M. (2010) Slappers Who Gouge Your Eyes: vocal performance as exemplification of disturbing inertia in gender equality. Gender and Education, 22 (1) 47 62. DOI 10.1080/09540250802213164, impact factor, 0.495 , ranked $66 / 188$

d) Journal Article: Ashley, M. (2011) The perpetuation of hegemonic male power and the loss of boyhood innocence: case studies from the music industry. Journal of Youth Studies, 14 (1), 59 -76. DOI 10.1080/13676261.2010.489603, impact factor 0.680

e) Journal Article: Ashley, M. (2011) The Angel Enigma: experienced boy singers' perceptual judgements of changing voices, Music Education Research, 13 (3) 343 - 354. DOI 10.1080/14613808.2011.603046, impact factor 0.404, ranking 9/84 (Music)

f) Journal Article: Ashley, M. (2012) Broken voices or a broken curriculum? the impact of research on UK school choral practice with boys, British Journal of Music Education, Firstview May 2013 CJO 2013 doi:10.1017/ S0265051713000090, impact factor 0.944, raking $65 / 216$

Examples of high quality virtual choral performances in well-resourced independent schools.

Roedean School

https://www.bing.com/videos/search?q=New+college+choir+virtual\&\&view=detail\&mid=136410E0038DAE9E 1090136410E0038DAE9E1090\&\&FORM=VRDGAR\&ru=\%2Fvideos\%2Fsearch\%3Fq\%3DNew\%2Bcollege\%2Bchoi r\%2Bvirtual\%26apvt\%3DNew\%2Bcollege\%2Bchoir\%2Bvirtual\%26FORM\%3DVDRE

New College Oxford

https://www.bing.com/videos/search?q=New+college+choir+virtual\&qpvt=New+college+choir+virtual\&view= detail\&mid=0FACF322E6D5D2F2A37D0FACF322E6D5D2F2A37D\&\&FORM=VRDGAR\&ru=\%2Fvideos\%2Fsearch \%3Fq\%3DNew\%2Bcollege\%2Bchoir\%2Bvirtual\%26qpvt\%3DNew\%2Bcollege\%2Bchoir\%2Bvirtual\%26FORM\%3D VDRE 